\title{
Peningkatan Kemampuan Guru-Guru SD Negeri 130 Palembang Dalam Menyajikan Presentasi Atraktif Melalui Pelatihan Microsoft Power Point
}

\author{
Irma Salamah $^{{ }^{*}}$, Lindawati ${ }^{2}$, Asriyadi $^{3}$, RD Kusumanto ${ }^{4}$ \\ 1,2,3,4 Jurusan Teknik Elektro Politeknik Negeri Sriwijaya \\ Email: irma,salamah@yahoo.com ${ }^{1}$ \\ *Penulis Korespodensi: Irma Salamah
}

\begin{abstract}
ABSTRAK
Pengembangan profesi guru adalah untuk menjaga dan meningkatkan kualitas guru agar semakin professional dalam melaksanakan tugasnya menggunakan media aplikasi Microsoft office power point. Ada beberapa faktor mengapa kegiatan ini diselenggarakan. Ada guru yang tidak terbiasa menggunakan teknologi sebagai media dalam pengajaran di kelas. Sekolah tidak menyediakan fasilitas yang memadai yang memungkinkan guru menciptakan media ajar mereka. Tidak adanya pembimbing dan pendampingan yang memberikan pendidikan singkat tentang bagaimana membuat media animasi untuk pengajaran di sekolah dasar. Dengan adanya pelatihan ini guru-guru SDN 130 Palembang diharapkan mampu menguasai dan memahami fitur dan fungsi yang ada pada Microsoft power point serta mampu membuat animasi untuk pembelajaran dengan menggunakan Microsoft power point.
\end{abstract}

Kata kunci: animasi pembelajaran; pelatihan microsoft power point; presentasi atraktif.

\section{ABSTRACT}

Teacher professional development is to maintain and improve the quality of teachers to be more professional in carrying out their duties using Microsoft Office Power Point application media. There are several factors why this activity is held. There are teachers who are not used to using technology as a medium in classroom teaching. Schools do not provide adequate facilities that allow teachers to create their teaching media. The absence of mentors and mentors who provide short education about how to make animation media for teaching in elementary schools. With this training the SDN 130 Palembang teachers are expected to be able to master and understand the features and functions that exist in Microsoft power point and be able to create animations for learning using Microsoft power point.

Keywords: attractif presentation; microsoft power point training; learning animation.

\section{PENDAHULUAN}

Seiring dengan perkembangan era globalisasi, dunia Teknologi Informasi dan Komunikasi juga berkembang dengan pesat dan pada abad 21 ini Teknologi Informasi dan Komunikasi sudah menjadi kebutuhan primer bagi banyak kalangan. Dengan menggunakan Teknologi Informasi dan Komunikasi, suatu proses dan kegiatan dapat dilakukan dengan lebih cepat, mudah dan efisien. Oleh karena itu penguasaan terhadap perangkat teknologi komunikasi perlu diajarkan pada semua tingkatan. 
Kemajuan suatu bangsa ditentukan oleh kemampuan para pendidiknya untuk mengubah karakter generasi penerusnya ke depan. Pencapaian Indonesia hingga saat ini tidak terlepas dari peran seorang guru yang telah membimbing anak muridnya menjadi manusia dewasa dan berperan aktif dalam pembangunan (Komang, 2013).

Pendidikan sebagai bagian dari sistem kehidupan di masyarakat tidak dapat dilepaskan dari perkembangan dan perubahan yang terjadi di masyarakat itu sendiri. Perubahan struktur dunia kerja yang diakibatkan pesatnya perkembangan ilmu pengetahuan dan teknologi serta diberlakukannnya era global menuntut lembaga pendidikan untuk benarbenar menghasilkan lulusan yang berkualitas dan memiliki daya saing kuat.

Perubahan struktur dunia kerja yang begitu cepat seiring pesatnya perkembangan ilmu pengetahuan dan teknologi menuntut tersedianya tenaga kerja yang berkualitas, mandiri dan produktif. Perguruan tinggi sebagai bagian dari pendidikan memiliki peran stragegis dalam menunjang pengembangan teknologi dan ilmu pengetahuan. Namun demikian dalam menjalankan misi sebagai lembaga pendidikan tinggi harus mampu mengikuti perkembangan teknologi dan informasi untuk mereduksi ketinggalan atau diskomunikasi dengan dunia luar. Perkembangan tentang informasi dan teknologi sangat penting mengingat setiap tahun atau bahkan setiap bulan ilmu pengetahuan dan informasi selalu berkembang.

Guru adalah sebuah profesi mulia karena di tangan merekalah masa depan bangsa ini ditentukan. Dalam melaksanakan kewajiban terpenting dari seorang guru yaitu mengajar maka guru perlu adanya suatu media pembelajaran. Media pembelajaran merupakan salah satu alat bantu seorang guru dalam memberikan pemahaman kepada siswanya (Riyanto, 2001).

Sistem pendidikan dewasa ini telah mengalami kemajuan yang sangat pesat. Berbagai cara telah dikenalkan serta digunakan dalam proses belajar mengajar (PBM) dengan harapan pengajaran guru akan lebih berkesan dan pembelajaran bagi murid akan lebih bermakna.

Proses belajar mengajar di sekolah mengalami situasi yang dinamis sesuai tuntutan atau perkembangan jaman. Tak heran jika sering berhadapan dengan materi yang sulit dipahami oleh peserta anak didik. Oleh karena itu guna memudahkan guru dalam menjelaskan materi maka perlu adanya media presentasi yang menarik sehingga minat belajar siswa meningkat (Resky, 2014).

Microsoft power point merupakan salah satu media presentasi atau publikasi yang dapat dipakai oleh guru untuk menyajikan materi pembelajarannya sehingga kegiatan belajar mengajar lebih interaktif dan menarik (Musfiqon, 2012). Khususnya bagi guru sekolah dasar memberikan suasana belajar yang menarik bagi siswanya sangatlah penting. 
Kebutuhan orang untuk memanfaatkan fasilitas microsoft office power point semakin meningkat, seiring dengan berkembangnya software yang dapat digunakan untuk proses pembelajaran. Pemanfaatan power point tidak hanya pada perguruan tinggi, tetapi sekolahsekolah mulai dari sekolah dasar (SD) hingga sekolah menengah atas (SMA) telah memanfaatkan power point sebagai penunjang proses belajar mengajar. Beberapa Sekolah Dasar (SD) yang telah memiliki fasilitas penunjang sebagai sarana pembelajaran. Namun beberapa kendala masih ada mengingat persentase guru yang mampu memanfaatkan power point masih kecil. Seperti dicontohkan di SD Negeri 130 Palembang, hanya sekitar 3 orang guru yang biasa memakai internet dan power point, sedang guru lainnya belum bisa mengoperasikan power point.

Untuk mencoba mengatasi permasalahan di SDN 130 Palembang tersebut maka dilakukan pelatihan power point yang di ikuti oleh guruguru dari SD tersebut. Dengan pelatihan ini diharapkan guru mampu menggunakan power point untuk keperluan penyerapan dan pengembangan ilmu pengetahuan serta memanfaatkan sebagai sarana komunikasi dan untuk media presentasi.

Kata media merupakan bentuk jamak dari kata medium. Medium dapat didefinisikan sebagai perantara atau pengantar terjadinya komunikasi dari pengirim menuju penerima.
Media merupakan salah satu komponen komunikasi, yaitu sebagai pembawa pesan dari komunikator menuju komunikan. Berdasarkan definisi tersebut, dapat dikatakan bahwa proses pembelajaran merupakan proses komunikasi. Proses pembelajaran mengandung lima komponen komunikasi, guru (komunikator), bahan pembelajaran, media pembelajaran, siswa (komunikan), dan tujuan pembelajaran (Brilianty, 2010).

Media pembelajaran dalam proses belajar mengajar dapat membangkitkan keinginan dan minat yang baru, membangkitkan motivasi dan rangsangan kegiatan belajar, dan bahkan membawa pengaruh pengaruh psikologi terhadap siswa.

Selain membangkitkan motivasi dan minat siswa, media pembelajaran juga dapat membantu siswa meningkatkan pemahaman, menyajikan data dengan menarik dan terpercaya, memudahkan penafsiran data, dan memadatkan informasi. Sedangkan menurut para pakar bahwa media pembelajaran meliputi alat yang secara fisik digunakan untuk menyampaikan isi materi pengajaran yang terdiri dari buku, tape recorder, kaset, video camera, video recorder, film, slide (gambar), foto, gambar, grafik, televisi dan computer.

Jadi, media pembelajaran adalah segala sesuatu yang dapat digunakan untuk menyalurkan pesan (bahan pembelajaran), sehingga dapat merangsang perhatian, minat, pikiran, dan perasaan siswa dalam kegiatan 
belajar mengajar untuk mencapai tujuan belajar (Estrada, 2010).

Media pembelajaran telah menjadi bagian integral dalam pembelajaran. Bahkan keberadaannya tidak bisa dipisahkan dalam proses pembelajaran di sekolah. Hal ini telah dikaji dan diteliti bahwa pembelajaran yang menggunakan media hasilnya lebih optimal. Walter Mc Kenzie (2005) dalam bukunya "Multiple Intelligences and Instructional Technology" mengatakan, media memiliki peran penting dalam pembelajaran di kelas, yang mempengaruhi kualitas dan keberhasilan pembelajaran. Dalam bagian ini dipaparkan berbagai fungsi media dalam pembelajaran.

Pada mulanya media hanya berfungsi sebagai alat bantu visual dalam kegiatan pembelajaran, yaitu berupa sarana yang dapat memberikan pengalaman visual kepada siswa antara lain untuk mendorong motivasi belajar, memperjelas dan mempermudah konsep yang kompleks dan abstrak menjadi lebih sederhana, konkrit, serta mudah difahami. Dengan demikian media dapat berfungsi untuk mempertinggi daya serap atau retensi belajar siswa terhadap materi pembelajaran (Estrada, 2010).

Oemar Hamalik dalam Heri Wibowo (2007) mengemukakan bahwa pemakaian media pembelajaran dalam proses belajar mengajar dapat membangkitkan keinginan dan minat yang baru, membangkitkan motivasi dan rangsangan kegiatan belajar, dan bahkan membawa pengaruh-pengaruh psikologis terhadap siswa. Penggunaan media pembelajaran pada tahap orientasi pembelajaran akan sangat membantu keefektifan proses pembelajaran dan penyampaian pesan dan isi pelajaran pada saat itu.

Selain membangkitkan motivasi dan minat siswa, media pembelajaran berbasis multimedia atau media pembelajaran juga dapat membantu siswa meningkatkan pemahaman, menyajikan data dengan menarik dan terpercaya, memudahkan penafsiran data, dan memadatkan informasi.

Angkowo dan Kosasih dalam Harison (2012) berpendapat bahwa salah satu fungsi media pembelajaran adalah sebagai alat bantu pembelajaran, yang ikut mempengaruhi situasi, kondisi dan lingkungan belajar dalam rangka mencapai tujuan pembelajaran yang telah diciptakan dan didesain oleh guru. Selain itu media dapat memperjelas pesan agar tidak terlalu bersifat verbal (dalam bentuk kata tertulis dan kata lisan belaka). Memanfaatkan media secara tepat dan bervariasi akan dapat mengurangi sikap pasif siswa.

Pemakaian media dalam proses pembelajaran akan dapat membangkitkan keinginan dan minat baru, membangkitkan motivasi dan rangsangan kegiatan belajar, serta membawa pengaruh psikologis terhadap siswa. Media juga dapat berguna untuk membangkitkan gairah belajar, memungkinkan siswa untuk belajar mandiri sesuai dengan minat dan kemampuannya. 
Media dapat meningkatkan pengetahuan, memperluas pengetahuan, serta memberikan fleksibilitas dalam penyampaian pesan. Selain itu media juga berfungsi sebagai alat komunikasi, sebagai sarana pemecahan masalah dan sebagai sarana pengembangan diri.

Pembelajaran atraktif adalah suatu proses pembelajaran yang mempesona, menarik, mengasyikkan, menyenangkan, tidak membosankan, variatif, kreatif dan indah. Dalam proses pembelajaran Sekolah Dasar sangat diperlukan proses pembelajaran yang atraktif. Sebab pada umumnya anak-anak pada usia sekolah dasar masih cepat bosan belajar dan berlatih, kegiatannya ditentukan oleh suasana hati dan menyenangi hal-hal yang indah, warna-warni, menggembirakan, dan mengumbar daya imajinasi yang tinggi dan liar. Pendidik hendaknya piawai dalam hal menciptakan proses pembelajaran yang mempesona dan membesut metode serta sarana yang mampu membuat mereka asyik belajar, bermain, melakukan sesuatu dengan variasi yang memadai. Pendidik harus kreatif dan inovatif dalam menciptakan alat dan sarana belajar, alat permainan serta lagu-lagu atau cerita-cerita sederhana dan ringkas. Sehingga tidak kekurangan akal dan sarana untuk mengaktifkan peserta didik dalam proses pembelajaran.

Keterpesonaan peserta didik dalam proses pembelajaran dapat ditentukan oleh karena keterampilan pendidik dalam mendongeng atau bercerita; keterampilan membuat alat dan sarana bermain; kepandaian pendidik dalam menyanyi, kreativitas pendidik dalam menggunakan barangbarang bekas menjadi alat peraga; keterampilan pendidik dalam memilih metode secara variatif; dan penciptaan suasana kelas yang menggembirakan, menyenangkan dan nyaman. Namun ada satu hal yang sangat penting dari semua itu yaitu kepandaian pendidik dalam membangun komunikasi dan keakraban dengan peserta didik. Komunikasi yang lancar, keakraban yang sangat erat akan menentukan semua proses pembelajaran menjadi atraktif.

Oleh karena itu tidak kalah pentingnya adalah penampilan profil pendidik di depan kelas. Apakah dalam berpakaian telah sewajarnya sesuai dengan tugas dan peran yang sedang dilakukan. Apakah ekspresi wajah dan tubuh menampakkan keceriaan, kebahagiaan, kegesitan, kelincahan. Apakah dalam ungkapan kata-kata dan perilaku lebih menunjukkan kesantunan, penghargaan yang positif terhadap anak-anak. Apakah pendidik mampu "mensejajarkan" diri dengan anakanak yang sedang dihadapinya. Sehinga peserta didik merasa nyaman, tentram, damai, senang dan bergairah dalam belajar dan berlatih. Singkatnya guru yang atraktif adalah guru yang memiliki pengetahuan dan keterampilan, serta sikap profesional dalam mengusahakan proses pembelajaran yang mempesona, menarik dan menyenangkan, yang dimulai dari penciptaan profil diri yang menarik dan mempesona bagi 
anak. Selain unsur pendidik, strategi pembelajaran, suasana kelas, pembelajaran atraktif juga ditentukan oleh keadaan kelas dan sarana prasarananya (Brilianty, 2010).

\section{Pengembangan Media Berbasis Multimedia (Microsoft Office PowerPoint)}

Power Point merupakan salah satu program dalam Microsoft Office. Power Point atau Microsoft Office PowerPoint adalah "sebuah program komputer untuk presentasi". Microsoft Office Power Point merupakan program aplikasi yang dirancang secara khusus untuk menampilkan program multimedia. Hal ini sebagaimana dikemukakan Resky (2014) sebagai berikut:

"Program Microsoft Office Power Point adalah salah satu software yang dirancang khusus untuk mampu menampilkan program multimedia dengan menarik, mudah dalam pembuatan, mudah dalam penggunaan dan relative murah karena tidak membutuhkan bahan baku selain alat untuk menyimpan data."

\section{Pakar Information Teknologi}

(IT) yang juga memberi pengertian yang tidak jauh berbeda dengan pengertian yang terdahulu, yaitu Microsoft Office PowerPoint adalah sebuah program komputer untuk presentasi yang dikembangkan oleh Microsoft di dalam paket aplikasi kantoran mereka, Microsoft Office, selain Microsoft Word, Excel, access dan beberapa program lainnya. PowerPoint berjalan di atas komputer PC berbasis Sistem Operasi Microsoft
Windows dan juga Apple Manchitos yang menggunakan sistem operasi Apple Mac OS, meskipun pada awalnya aplikasi ini berjalan di atas sistem operasi Xenix. Aplikasi ini sangat banyak digunakan, apalagi oleh kalangan perkantoran dan pebisnis, para pendidik, peserta didik, dan trainer.

PowerPoint inilah yang dikembangkan oleh Microsoft di dalam paket aplikasi kantoran mereka, Microsoft Office, selain Microsoft Word, Excel, Access dan beberapa program lainnya. PowerPoint berjalan di atas komputer PC berbasis sistem operasi Microsoft Windows dan juga Apple Macintosh yang menggunakan sistem operasi Apple Mac OS, meskipun pada awalnya aplikasi ini berjalan di atas sistem operasi Xenix. Aplikasi ini sangat banyak digunakan, apalagi oleh kalangan perkantoran dan pebisnis, para pendidik, peserta didik, dan trainer untuk presentasi (Asih, 2013).

Power Point dapat menyimpan presentasi dalam beberapa format, yakni sebagai berikut.

1. PPT (PowerPoint Presentation), yang merupakan data biner dan tersedia dalam semua versi PowerPoint (termasuk PowerPoint 12).

2. PPS (PowerPoint Show), yang merupakan data biner dan tersedia dalam semua versi PowerPoint (termasuk PowerPoint 12).

3. POT (PowerPoint Template), yang merupakan data biner dan tersedia dalam semua versi PowerPoint (termasuk PowerPoint 12). 
4. PPTX (PowerPoint Presentation), yang merupakan data dalam bentuk XML dan hanya tersedia dalam PowerPoint 12.

Dimulai pada versi Microsoft Office System 2003, Microsoft mengganti nama dari sebelumnya Microsoft PowerPoint saja menjadi Microsoft Office PowerPoint. "Versi terbaru dari PowerPoint adalah versi 12 (Microsoft Office PowerPoint 2007), yang tergabung ke dalam paket Microsoft Office System 2007”.

Microsoft Powerpoint 2007 adalah program aplikasi presentasi yang merupakan salah satu aplikasi di bawah Microsoft Office”.

Pada umumnya Microsoft Office Power Point digunakan untuk presentasi dalam classical learning, karena Microsoft Office Power Point merupakan program aplikasi yang digunakan untuk kepentingan presentasi. Berdasarkan pola penyajian yang telah dikemukakan sebelumnya bahwa Microsoft Office Power Point yang digunakan untuk presentasi dalam classical learning disebut personal presentation. Microsoft Office Power Point pada pola penyajian ini digunakan sebagai alat bantu bagi guru untuk menyampaikan materi dan kontrol pembelajaran terletak pada guru.

\section{Desain tampilan pengembangan media pembelajaran berbasis Berbasis Power Point}

Media pembelajaran yang baik harus memenuhi berbagai kriteria. Beberapa kriteria diantaranya adalah menarik dan benar-benar mampu membantu siswa mencapai tujuan pembelajaranya (Asih, 2013).

Dalam media pembelajaran berbasis multimedia, visualisasi pesan, informasi, atau konsep yang ingin disampaikan kepada siswa merupakan bagian yang sangat penting. Penataan elemen-elamen visual harus dapat menampilkan visual yang dapat dimengerti, terang/dapat dibaca, dan dapat menarik perhatian sehingga mampu menyampaikan pesan yang diinginkan oleh penggunanya. Dalam proses penataan ini harus diperhatikan prinsip-prinsip desain tertentu, antara lain sebagai berikut.

1. Kesederhanaan

Secara umum kesederhanaan mengacu pada banyaknya elemen yang terkadung dalam suatu visual. Elemen yang lebih sedikit memudahkan bisa menagkap dan memahami pesan yang disajikan secara visual. Pesan atau informasi yang panjang atau rumit harus dibagi-bagi kedalam beberapa bahan visual yang mudah dibaca dan mudah dipahami. Demikian pula banyaknya taks untuk menyertai bahan visual harus di batasi (misalnya antar 15 sampai 20 kata).

2. Keterpaduan

Keterpaduan mengacu pada hubungan yang terdapat diantara elemen-elamen visual yang ketika diamati akan berfungsi secara bersama-sama. Elemen-elemen itu harus saling terkait dan menyatu sebagai suatu keseluruhan sehingga visual itu merupakan bentuk yang utuh, menyatu yang 
dapat membantu pemahaman pesan dan informasi yang dikandungnya.

3. Penekanan

Meskipun penyajian visual dirancang sesederhana mungkin, seringkali konsep yang ingin disajikan memerlukan penekanan terhadap salah satu unsure yang akan menjadi pusat perhatian siswa. Dengan menggunakan ukuran, hubungan-hubungan, perspektif, warna atau ruang penekanan dapat diberikan kepada unsur terpenting.

4. Keseimbangan

Bentuk atau pola yang dipilih sebaiknya menempati ruang penayangan yang memberikan persepsi keseimbangn meskipun tidak seluruhnya simetris.

Unsur-unsur visual yang selanjutnya perlu dipertimbangkan antara lain sebagai berikut.

1. Bentuk

Bentuk yang aneh dan asing bagi siswa dapat membangkitkan minat dan perhatian. Oleh karna itu, pemilihan bentuk sebagai unsure visual dalam penyajian pesan, informasi atau isi pelajaran perlu diperhatikan.

2. Garis

Garis digunakan untuk menghubungkan unsur-unsur sehingga dapat menuntun perhatian sisiwa untuk mempelajari suatu urutanurutan khusus.

3. Warna

Warna digunakan untuk memberikan kesan pemisahan dan penekanan, atau untuk mem- bangun keterpaduan. Disamping itu, warna dapat mempertinggi tingkat realistic (nyata) obyek atau situasi yang digambarkan, menunjukkan persamaan dan perbedaan dan menciptakan respon emotional tertentu. Beberapa pertimbangan yang harus diperhatikan ketika menggunakan warna yaitu sebagai berikut.

a. Banyaknya warna yang dipergunakan untuk penyajian visual masimum 5corak

b. Warna yang terang dan kuat digunakan untuk menarik perhatian.

c. Warna-warna panas seperti merah, oranye dan kuning digunakan untuk mengenali aksi, seperti kebutuhan untuk memberikan respon.

d. Warma kalem (cool colors) seperti hijau, biru, dam violet digunakan untuk menunjukkan keadaan tetap (status quo) atau latar belakang informasi.

e. Perubahan warna (sebagaimana penambahan intesitas warna) digunakan untuk menunjukkan perubahan progresif dalm nnilai atau tahapan-tahapan sekuen.

\section{METODE}

Metode yang diterapkan dalam pelatihan ini adalah sebagai berikut.

1. Metode presentasi

Metode presentasi diterapkan dalam pengenalan software, kemanfaataannya, dan penerapannya dalam pembuatan media pembelajaran interaktif. 
2. Metode demonstrasi

Metode Demonstrasi mengenai pengoperasionalisasian program

3. Metode praktik

Metode Praktik dimana guruguru mempraktikkan secara langsung pembuatan media pembelajaran sesuai mata pelajaran masing-masing dengan pemanfaatan program Microsoft Power Point.

\section{HASIL DAN PEMBAHASAN}

Bentuk langkah-langkah kongkrit yang dilaksanakan dalam pelatihan ini sehingga pelatihan ini dapat berhasil dilaksanakan adalah sebagai berikut.

1. Melakukan identifikasi materi power point, dilakukan dengan menanyakan langsung kepada Kepala Sekolah dan Guru yang ada di SDN 130 Palembang.

2. Melakukan pelatihan power point dengan panduan modul

Pemakaian modul d telah kami terapkan pada pelatihan ini. Modul yang kami siapkan sudah digandakan sekitar 10 buah.

3. Pemantauan dan diskusi pemecahan masalah

Pemantauan dan diskusi telah dilaksanakan pada saat pelaksanaan pelatihan dilaksanakan. Banyak pertanyaan yang diajukan oleh peserta, dan mereka umumnya meminta untuk didampingi secara individu agar cepat menguasai materi yang disampaikan. Pendampingan ini dilaksanakan oleh 4 orang, dan peserta yang mengikuti pelatihan sekitar \pm 40 orang.
Faktor pendukung dalam melaksanakan program pelatihan ini adalah adanya dukungan dana dari pihak Polsri. Hal lain yang juga sangat mendukung adalah motivasi guruguru SDN 130 Palembang dalam mengikuti pelatihan yang terbukti lebih dari 50\% guru SDN 130 Palembang mengikuti pelatihan ini.

Secara prinsip tidak ditemukan faktor penghambat yang berarti. Namun yang menjadi sedikit hambatan adalah jadwal pelaksanaan yang harus menyesuaikan dengan kesibukan dari tim Pengabdi dan kesibukan dari guru-guru SDN 130 Palembang.

Berdasarkan pengamatan dan evaluasi yang dilakukan selama pelatihan, dapat dilaporkan bahwa kegiatan pengabdian yang bertempat di SDN 130 Palembang telah berhasil dilaksanakan dengan materi power point yang dilaksanakan selama 1 hari ( \pm 10 jam). Indikator keberhasilan yang telah dicapai dalam pelatihan ini daat dilihat dari pencapaian kompetensi guru (peserta pelatihan) yang dilihat dari pengamatan selama proses pelatihan, yaitu: Peserta dapat membuat tulisan, membuat rancangan tampilan, mengatur animasi tampilan pada program power point untuk kebutuhan presentasi.

Berikut foto-foto dokumentasi pengabdian.

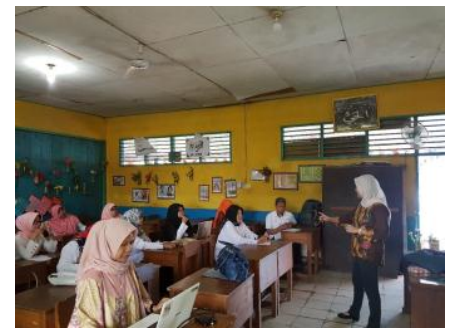



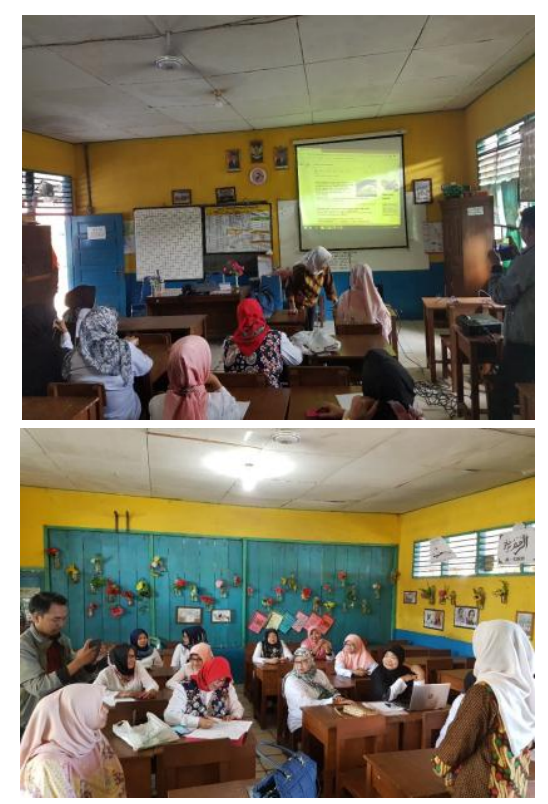

\section{SIMPULAN}

Adapun kesimpulan yang dapat diambil dari pengabdian ini adalah sebagai berikut.

1. Tim PPM dari Jurusan Teknik Elektro Polsri telah berhasil melaksanakan program pelatihan internet dan power point di SDN 130 Palembang.

2. Guru- guru di SDN 130 Palembang memberikan tanggapan yang antusias pada pelatihan ini dilihat dari jumlah kehadiran guru maupun respon saat pelatihan.

3. Terjalin kemitraan dan kerjasama antara pihak Polsri dan SDN 130 Palembang.

Berdasarkan masukan dari pihak sekolah, perlu diadakan kegiatan lanjutan program pelatihan seperti ini untuk materi lain, seperti MS Excel yang banyak dipakai untuk perhitungan nilai siswa dan MS Word untuk membuat karya ilmiah.

\section{DAFTAR PUSTAKA}

Asih Widi Harini Ridwan. 2013. Panduan Cepat Kuasai Microsoft Office Powerpoint 2010. Penerbit : Baduose Media. Yogyakarta : 2010

Brilianty Wijaya. 2010. Media Pembelajaran Atraktif. [Online]. http://brilianty-wijaya2010.blogspot.com/2013/05/medi a-pembelajaran-atraktif.html. [8 November 2018]

Estrada, E. dkk. 2010. Media Pembelajaran. [Online]. http://ejournal.unesa.ac.id/article/ 3084/12/article.docx. [8 Oktober 2018]

Heri Wibowo, Mujiono, Arianto Leman, Didik Nurhadiyanto. 2007. Pelatihan Internet dan Power Point Untuk Guru-Guru di SMPN 1 Sleman. Laporan PPM. Universitas Negeri Yogyakarta.

Harison, dkk. 2012. Pelatihan Pembuatan Media Pembelajaran Menggunakan Microsoft Power Point Untuk Para Guru SD di Kecamatan Tapung Kab Kampar. Laporan PPM. Universitas Riau.

Komang Meilani. 2013. Pembelajaran Atraktif. [Online]. https://komangmeliani.wordpress .com, [5 November 2018]

Musfiqon, HM. (2012). Pengembangan Media dan Sumber Pembelajaran, [Online]. http://prestasipustakaraya.com/m edia-dan-sumber-belajarpengembangan-media-dansumber-pembelajaran-penulis-dr- 


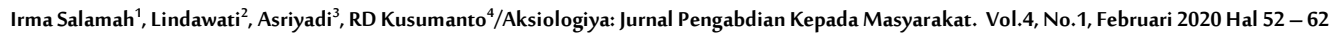

hm-musfiqon-m-pd.html/. $\quad$ [8 Resky, Rhayanti. 2014. Media November 2018] Pembelajaran Berbasis Power Point. [Online].

Riyanto, Br. T. 2002. Pendidikan dan http://rhayanti.blogspot.com/201 Pembelajaran Atraktif, [Online]. http://www.bruderfic.or.id/h-57/. [9 November 2018] 4/10/media-pembelajaranberbasis-power-point.html. [ 12 November 2018] 